\title{
PENINGKATAN SOFT SKILLS SISWA SMP MELALUI PEMBELAJARAN GENERATIF
}

\author{
La Moma \\ FKIP Universitas Pattimura Ambon \\ email:lamoma96@yahoo.com
}

\begin{abstract}
Abstrak: Soft skills merupakan faktor yang turut menunjang kesuksesan siswa belajar matematika. Perlu ada upaya untuk menerapkan suatu model pembelajaran yang dapat memicu peningkatan soft skills siswa dalam matematika. Penelitian ini menerapkan model pembelajaran generatif sebagai alternatif pembelajaran yang diperkirakan akan memicu peningkatan ketiga kemampuan tersebut. Tujuan penelitian untuk mengetahui seberapa besar kontribusi penerapan model tersebut terhadap peningkatan kemampuan soft skills pada level sekolah (tinggi, sedang dan rendah). Penelitian menerapkan desain kuasi eksperimen. Sampel terdiri atas 191 orang siswa kelas VIII pada tiga SMP Negeri di Kota Yogyakarta yang mewakili level sekolah. Pengumpulan data dilakukan dengan teknik tes (pretes dan postes), sedang analisis data menggunakan statistik uji-t dan anova dua jalur. Dari hasil analisis data ditemukan bahwa (1) ada perbedaan pencapaian, peningkatan soft skills siswa antara kelas eksperimen dan kelas kontrol; (2) tidak terdapat interaksi antara pembelajaran dan level sekolah terhadap peningkatan soft skills.
\end{abstract}

Kata Kunci: kemampuan soft skills, pembelajaran generatif

\section{THE ENHANCEMENT OF JUNIOR HIGH SCHOOL STUDENTS SOFT SKILLS THROUGH GENERATIVE LEARNING}

\begin{abstract}
Soft skills are factors that support students success in learning mathematics. The importance of the students soft skills, unfortunately, are not in line with at the students abilities in these competence. Therefore, we have to implemented a learning model that is expected to lead development soft skills of the students in mathematics. Generative learning model is applied in this study as an alternative learning is predicted to stimulate development soft skills of the students. This study is aimed at determining the contribution of generative learning model of the enhancement of soft skills for difference school levels (high, medium, low).This study is quasi-experimental research involving 191 students of eight-grade senior high schools in Yogyakarta involving three levels of school. Research hyphothesis was examined at 5\% level of significance, data analyzed using t-test, and twoway ANOVA. The results of the study are: (1) there are different achievement, the enhancement of soft skills of student between experiment of class and control class; (2) there is no interaction betwee learning and school level toward the enhancemen soft skills.
\end{abstract}

Keywords: soft skills, generative learning

\section{PENDAHULUAN}

Untuk memperoleh sumber daya manusia yang berkualitas, seseorang tidak hanya dituntut memiliki kemampuan hard skills saja, tetapi juga kemampuan soft skills. Berdasarkan hasil penelitian dari Harvard University, Amerika Serikat, yang mengagetkan dunia pendidikan di Indonesia menurut penelitian tersebut, kesuksesan seseorang tidak ditentukan semata-mata oleh pengetahuan dan kemampuan teknis (hard skills) saja, tetapi oleh keterampilan mengelola diri dan orang lain (soft skills) (Muqowin, 2012: 3). Selanjutnya, hasil penelitian psikologi sosial menunjukkan bahwa orang yang sukses di dunia ditentukan oleh peranan ilmu sebesar $18 \%$. Sisanya, 82\% ditentukan oleh keterampilan emosional, soft skills dan sejenisnya (Elfindri dkk, 2010: 68).

Gardner (1993:24) mengemukakan bahwa ada dua kecerdasan yang berkaitan dengan kemampuan mengembangkan kepribadian, yakni kecerdasan interpersonal dan kecerdasan intra- 
personal. Kecerdasan interpersonal yaitu kemampuan untuk mengerti dan menjadi peka terhadap perasaan, intensi, motivasi, watak, dan temperamen orang lain, dan kemampuan untuk menjalin relasi dan komunikasi dengan orang lain. Kecerdasan intrapersonal adalah kemampuan memahami diri dan bertindak adaptif berdasarkan pengetahuan tentang diri. Kemampuan berefleksi dan keseimbangan diri, kesadaran diri tinggi, inisiatif dan berani. Pendapat ini sejalan dengan Goleman (1999:45), bahwa kecerdasan emosional merujuk pada kemampuan mengenali perasaan diri sendiri dan perasaan orang lain, kemampuan memotivasi diri sendiri dan kemampuan mengelola emosi dengan baik pada diri sendiri dan dalam hubungan dengan orang lain.

Masalah pokok yang perlu dicermati dari paparan di atas adalah siswa tidak hanya menguasai ilmu pengetahuan, teknologi, atau seni pada bidang tertentu, tetapi juga perlu menguasai keterampilan tambahan, seperti: kemampuan berkomunikasi secara efektif, kemampuan berpikir logis, kemampuan bekerja sama, kemampuan belajar, dan lain-lain. Dengan kata lain, siswa perlu memiliki kemampuan softskills yang baik.

Dalam kenyataannya, praktik pendidikan di Indonesia saat ini masih lebih banyak memberikan porsi pada kemampuan pengetahuan dan keterampilan, bahkan dapat dikatakan lebih berorientasi pada pembelajaran hard skills. Artinya, siswa diberi keahlian akademik dan kompetensi teknikal saja, misalnya siswa diberi keterampilan menyelesaikan masalah terkait dengan matematika. Jika melihat realita dalam pembelajaran yang dilakukan di sekolah, terkait dengan memberikan materi pelajaran matematika, guru cenderung lebih memilih cepat menyelesaikan materi yang diajarkan, tanpa perhatian pada peningkatan yang proporsional terhadap kreativitas siswa, sikap kerja keras siswa, kurang memberikan kebebasan siswa untuk mengungkapkan ide atau gagasan baru, dan berkomunikasi antara teman dalam kelompok dalam penyelesaian suatu masalah.

Soft skills berada pada ranah teknis dan akademik, lebih bersifat psikologis sehingga abstrak. Soft skills merupakan suatu istilah sosio- logis yang merepresentasikan pengembangan kecerdasan emosional seseorang yang merupakan kumpulan karakter kepribadian, kepekaan sosial, komunikasi, bahasa, kebiasaan pribadi, keramahan, dan optimis yang menjadi ciri hubungan dengan orang lain. Alfindri, dkk. (2009: 7) mengemukakan bahwa soft skills merupakan keterampilan seseorang dalam hubungan dengan orang lain (interprosonal skills), dan keterampilan dalam mengatur dirinya sendiri (intrapersonal skills) yang mampu mengembangkan produktivitas kerja secara maksimal, sedangkan hard skills, yaitu penguasaan ilmu pengetahuan, teknologi dan keterampilan teknis yang berhubungan dengan ilmunya.

Mengingat pentingya soft skills dalam upaya membentuk karakter siswa, strategi pembelajaran yang bisa dikembangkan adalah mengoptimalkan interaksi antara guru dengan siswa, siswa dengan siswa, guru dengan siswa dan menghasilkan lingkungan yang sehat dan kaya, serta interaksi banyak arah. Di samping itu, perlu juga kreativitas guru dalam memancing siswa untuk terlibat secara aktif, baik fisik, mental, sosial dan emosional. Dengan demikian, bila hal itu sudah terbiasa dilakukan oleh siswa, dengan sendirinya akan terbawa saat mereka terjun di dunia kerja dan di masyarakat.

Kenyataan di lapangan, guru-guru matematika sekolah menengah pertama (SMP) jarang memberi perhatian yang proporsional dalam meningkatkan kemampuan soft skills siswa. Rendahnya kemampuan softs kills siswa sekolah menengah pertama (SMP) merupakan permasalahan penting dalam pendidikan matematika. Diduga karena faktor model pembelajaran yang digunakan kurang menyenangkan, kurang partisipasi siswa dalam pembelajaran serta lingkungan belajar yang kurang konduksif. Oleh karena itu, diperlukan suatu model pembelajaran matematika yang dipandang tepat sehingga dapat meningkatkan kemampuan soft skills siswa tersebut.

Hasil penelitian yang terkait dengan soft skills siswa antara lain: Cangelosi dan Petersen (Widhiarso, 2009:3) yang menemukan bahwa banyak kegagalan siswa di sekolah, masyarakat, dan tempat kerja diakibatkan rendahnya kete- 
rampilan dalam berkomunikasi. Sejalan dengan hal itu, Shapiro (1997:161) mengemukakan bahwa keterampilan EQ yang melibatkan logika dan bahasa dalam bagian otak berpikir, diperlukan cukup banyak latihan agar anak-anak dapat secara otomatis mulai menghubungkan masalah dengan solusi-solusi yang mungkin. Nyoman (2009:73) mengemukakan bahwa bahwa pendekatan SHIP untuk mengembangkan soft skills mahasiswa terutama dalam merencanakan kegiatan kemahasiswaan hendaknya melibatkan lebih banyak mahasiswa, baik mahasiswa yang aktivitas maupun mahasiswa yang tidak aktif.

Hasil temuan Abdullah (2012:21) menunjukkan bahwa peningkatan kemampuan pemahaman matematis dan representasi siswa yang memperoleh pembelajaran kontekstual berbasis soft skills lebih tinggi (kategori sedang) daripada siswa yang memperoleh pembelajaran konvesional (kategori rendah), ditinjau dari keseluruhan. Salah satu model pembelajaran yang diperkirakan dapat meningkatkan kemampuan soft skills siswa dalam pembelajaran matematika adalah pembelajaran generatif. Pembelajaran generatif merupakan suatu model pembelajaran berbasis konstruktivisme yang lebih menekankan pada pengintegrasian secara aktif pengetahuan baru dengan menggunakan pengetahuan yang sudah dimiliki siswa sebelumnya. Model pembelajaran generatif menuntut siswa untuk aktif, dan bebas mengkonstruksi pengetahuannya. Selain itu, siswa juga diberi kebebasan untuk mengungkap ide atau gagasan dan alasan terhadap permasalahan yang diberikan sehingga akan lebih memahami pengetahuan yang dibentuknya sendiri dan proses pembelajaran yang dilakukan akan lebih optimal.

Osborne \& Wittrock (1985:65) mengemukakan bahwa penerapan model pembelajaran generatif merupakan suatu cara yang baik untuk mengetahui pola berpikir siswa serta bagaimana siswa memahami dan memecahkan masalah dengan baik agar dalam pembelajaran nanti guru dapat menyusun strategi dalam pembelajaran, misalnya bagaimana menciptakan suasana pembelajaran yang menarik, menyenangkan, dan sebagainya. Hasil temuan Fahinu (2007:164) bahwa kemandirian belajar mahasiswa yang diajar dengan pendekatan pembelajaran generatif lebih baik daripada mahasiswa yang diajarkan dengan pendekatan pembelajaran konvesional. Temuan Haji (2011:60) juga menunjukkan bahwa terdapat perbedaan kemampuan berpikir asli siswa SMP yang diajarkan dengan menggunakan pembelajaran generatif dengan pendekatan open-ended dengan pembelajaran biasa.

Uraian di atas menunjukkan bahwa pembelajaran generatif dapat memberikan tantangan kepada siswa untuk memecahkan suatu permasalahan matematis dan mendorong siswa untuk lebih kreatif, termotivasi belajar, percaya diri, serta dapat mendorong tumbuhnya kemampuan soft skills siswa. Dalam proses pembelajaran matematika guru dituntut untuk menggunakan masalah-masalah non rutin dan bersifat terbuka (open-ended) dalam penyelesaian suatu masalah dalam pembelajaran matematika.

Hasil observasi awal yang dilakukan oleh peneliti pada beberapa SMP di Kota Yogyakarta juga menunjukkan bahwa siswa SMP dalam proses pembelajaran matematika masih banyak yang belum mampu mengungkapkan ide atau gagasannya, berkomunikasi dengan efektif, berpikir kritis, kreatif, bekerjasama dalam tim dan cenderung hanya mengikuti apa yang dicatat oleh guru di papan tulis, cenderung pasif, semangat belajarnya kurang, dan kurang rasa percaya diri saat menyampaikan pendapatnya di hadapan teman-temannya. Dengan kata lain, siswa yang memiliki rasa percaya diri yang tinggi akan memberi manfaat yang positif dalam upaya peningkatan soft skills siswa dalam pembelajaran matematika.

Tujuan penelitian ini adalah untuk mengetahui pencapaian dan peningkatan soft skills siswa yang memperoleh pembelajaran generatif dan siswa yang memperoleh pembelajaran konvensional serta pengaruh interaksi antara pembelajaran (MPG dan MPK) dan level sekolah (tinggi, sedang, rendah) terhadap peningkatan soft skills siswa SMP.

\section{METODE}

Jenis penelitian ini adalah kuasi eksperimen dengan desain kelompok kontrol pretespostes. Pada penelitian kuasi eksperimen ini 
subjek tidak dikelompokkan secara acak, tetapi berdasarkan keadaan subjek seadanya (Ruseffendi, 2005:52). Pada tahap awal penelitian ini ditetapkan sampel sekolah ke dalam peringkat tinggi, sedang, dan rendah. Selanjutnya, dari tiap sekolah diambil dua kelas secara acak sebagai kelas eksperimen dan kelas kontrol. Perlakuan ini diberikan untuk dilihat pengaruhnya terhadap aspek yang diukur, yaitu kemampuan soft skills siswa. Desain penelitian yang digunakan dalam penelitian ini sebagai berikut .

$$
\begin{array}{crr}
O & X & O \\
\hdashline & & O
\end{array}
$$

Pengelompokan subjek penelitian dilakukan secara acak kelas, kelompok eksperimen diberi perlakuan pembelajaran generatif (X), sedang kelompok kontrol diberi pembelajaran konvensional, kemudian masing-masing kelas penelitian diberi pretes dan postes (O). Subjek penelitian adalah sebanyak 191 orang siswa SMP kelas VIII yang berasal dari peringkat sekolah di Kota Yogyakarta yang masing-masing mewakili level sekolah (tinggi, sedang, dan rendah). Pemilihan ketiga sekolah di atas ditetapkan dengan menggunakan teknik stratified random sampling, sedangkan penetapan kelas pada setiap sekolah dilakukan dengan menggunakan teknik acak kelompok kelas.

Definisi operasional dalam penelitian adalah model pembelajaran generatif adalah model pembelajaran berbasis konstruktivisme, yang lebih menekankan pada pengintegrasian secara aktif pengalaman baru dengan menggunakan pengetahuan yang dimiliki siswa sebelumnya, melalui lima tahapan, yaitu (1) orientasi; (2) mengungkapan ide; (3) tantangan dan restrukturisasi; (4) penerapan; (5) melihat kembali. Soft skills adalah keterampilan yang dimiliki seseorang dalam berhubungan dengan orang lain termasuk dirinya sendiri yang meliputi keterampilan komunikasi efektif, keterampilan membangun kerja sama tim, kreativitas, kritis, kepercayaan diri, dan pemecahan masalah dalam pembelajaran matematika.
Variabel penelitian ini terdiri atas tiga variabel, yaitu: (1) variabel bebas meliputi pembelajaran; (2) variabel terikat meliputi soft skills (SS) siswa; dan (3) variabel kontrol meliputi level skolah (tinggi, sedang, rendah). Instrumen yang digunakan untuk mengukur soft skills siswa dalam penelitin ini adalah angket soft skillssiswa yang terdiri 25 item. Tes dilakukan ada dua kali, yaitu pretes dilakukan sebelum pembelajaran dan postes dilaksanakan setelah pembelajaran. Analisis data dilakukan dengan teknik statistik uji t dan anova dua jalur.

\section{HASIL DAN PEMBAHASAN}

\section{Pencapaian Soft Skills Siswa Berdasarkan Kelompok Pembelajaran dan Level Sekolah}

Analisis data untuk mengetahui pencapaian soft skills siswa akan dilakukan dengan memanfaatkan skor postes siswa, baik dari kelompok eksperimen (MPG) maupun dari skor postes siswa dari kelompok (MPK). Data tes angket soft skills siswa diperoleh dari 191 orang siswa yang terbagi atas dua bagian, yaitu 95 orang siswa untuk kelompok eksperimen dan 96 orang siswa untuk kelompok kontrol. Deskripsi data pencapaian soft skills siswa meliputi skor rata-rata, simpangan baku (SB). Pada Tabel 1 ditunjukkan rata-rata pencapaian soft skills siswa berdasarkan pembelajaran dan level sekolah.

Tebel 1. Rata-rata Pencapaian Soft Skills Siswa Berdasarkan Kelompok Pembelajaran dan Level Sekolah

\begin{tabular}{cl}
\hline Level Sekolah & \multicolumn{1}{c}{ PembelajaranNRata-rataSB } \\
\hline Tinggi & MPK3195,5934,032 \\
& MPK3187,2986,099 \\
Sedang & MPG3392,8239,683 \\
& MPK3386,1037,109 \\
Rendah & MPG3191,8235,436 \\
& MPK3287,7334,569 \\
\hline
\end{tabular}

Keterangan:Skor maksimum ideal $=135,025$

Kualitas pencapaian soft skills siswa pada masing-masing level sekolah (tinggi, sedang, dan rendah) yang memperoleh MPG cenderung memperoleh skor rata-rata postes lebih besar bila dibandingkan dengan skor rata-rata postes soft skills siswa yang memperoleh pembelajaran 
konvensional (MPK). Perbandingan skor ratarata postes soft skills siswa antara kelompok pembelajaran (MPG dan MPK) level sekolah (tinggi, sedang, dan rendah), terlihat bahwa skor rata-rata pencapaian soft skills siswa adalah sebagai berikut. Siswa pada level sekolah tinggi dengan menggunakan pembelajaran generatif (MPG) memiliki skor rata-rata postes lebih besar dari skor rata-rata postes yang dicapai oleh siswa dengan memperoleh pembelajaran konvensional (MPK). Demikian pula yang dicapai oleh siswa pada level sekolah sedang, dan level sekolah rendah.

Berdasarkan uraian di atas, dapat disimpulkan bahwa siswa pada semua level sekolah (tinggi, sedang, dan rendah) yang memperoleh MPG mempunyai skor rata-rata pencapaian lebih besar dari siswa yang memperoleh MPK.

Untuk mengetahui ada atau tidaknya perbedaan rata-rata kedua kelompok data dilakukan pengujian dengan menggunakan analisis statistik uji-t. Hasil pehitungan dari uji-t kedua kelompok data tersebut dilihat pada Tabel 2.

Tabel 2. Hasil Uji-t Data Postes Soft Skills Siswa Berdasarkan Kelompok Pembelajaran

\begin{tabular}{cl}
\hline Kelompok & \multicolumn{1}{c}{ Soft skills Siswa } \\
\cline { 2 - 2 } Pembelajaran & $\begin{array}{l}\text { Perb. Rata-rata } \\
\text { Postes }\end{array}$ \\
& Sig.(2-pihak) $\mathrm{H}_{\mathrm{o}}$ \\
\hline MPG dengan & $\begin{array}{l}\text { 93,401> 87,0326,6480,000 } \\
\text { MPK }\end{array}$ \\
\hline
\end{tabular}

Keterangan $\mathrm{H}_{0}$ : Tidak ada perbedaan pencapaian soft skills siswa antara kedua kelompok pembelajaran (eksperimen dan konvensional) secara keseluruhan

Skor rata-rata postes siswa kelompok MPG lebih besar dibandingkan dengan skor rata-rata pencapaian kelompok MPK, sehingga dapat dikatakan bahwa ada perbedaan yang signifikan skor rata-rata pencapaian siswa antara kelompok eksperimen (MPG) dengan kelompok kontrol (MPK). Dengan demikian, dapat disimpulkan bahwa pencapaian soft skills siswa yang memperoleh MPG berbeda secara signifikan dibandingkan dengan siswa yang memperoleh MPK pada semua level sekolah (tinggi, sedang, dan rendah). Namun, secara keseluruhan pencapaian soft skills siswa termasuk kategori level sedang.

\section{Peningkatan Soft Skills Siswa Berdasarkan Kelompok Pembelajaran}

Analisis data untuk mengetahui peningkatan soft skills antara siswa yang menggunakan MPG dan menggunakan MPK dengan menganalisis data postes. Rerata, Gain ternormalisasi (N-Gain), maksimum dan minimum yang diperoleh dari perhitungan ini yang merupakan gambaran peningkatan soft skills siswa yang memperoleh MPG dan siswa yang memperoleh MPK disajikan pada Tabel 3.

Skor rata-rata $\mathrm{N}$-Gain dan simpangan baku soft skills siswa antara kelompok eksperimen (MPG) terlihat lebih besar dibandingkan dengan kelompok kontrol (MPK). Hal ini mengindikasikan bahwa peningkatan soft skills siswa pada kelompok MPG lebih baik daripada yang memperoleh MPK. Untuk mengetahui ada atau tidaknya perbedaan signifikansi soft skills siswa digunakan uji-t. Pada bagian berikut akan disajikan hasil uji perbedaan peningkatan soft skills siswa berdasarkan pembelajaran dan level sekolah secara keseluruhan.Hasil pengujian dapat disajikan Tabel 4.

Skor rata-rata N-Gain soft skills siswa yang memperoleh pembelajaran generatif pada seluruh level sekolah (tinggi, sedang, dan rendah) lebih besar bila dibandingkan dengan skor rata-rata N-Gain siswa yang memperoleh pembelajaran konvensional pada setiap level sekolah (tinggi, sedang, dan rendah). Bila dilihat dari nilai $t$, berarti ada perbedaan yang signifikan peningkatan soft skills siswa antara kelompok eksperimen (MPG) dan kelompok kontrol (MPK) pada semua level sekolah. Secara keseluruhan peningkatan soft skills siswa dengan menggunakan pembelajaran generatif termasuk katagori level rendah. 
Tabel 3. Data N-Gain Soft Skills Siswa Berdasarkan Kelompok Pembelajaran

\begin{tabular}{lcllll}
\hline Kelompok N- Gain Soft skills & & & & & \\
& & & & & \\
& & & & \\
& & Rerata & Simp Baku & Min & Max. \\
\hline Eskperimen (MPG) & 95 & 0,191 & 0,15 & $-0,49$ & 0,63 \\
Kontrol (MPK) & 960,038 & 0,156 & $-0,58$ & 0,38 & \\
\hline
\end{tabular}

Tabel 4. Hasil Uji-t Data N-Gain Soft Skills Siswa Berdasarkan Kelompok Pembelajaran

\begin{tabular}{|c|c|c|c|}
\hline \multirow[t]{2}{*}{ Pembelajaran } & \multicolumn{3}{|c|}{ Soft skills } \\
\hline & Perb. rata-rata N-Gain & $\mathrm{t}$ & Sig.(2-pihak) $H_{o}$ \\
\hline MPG dengan MPK & $0,19>0,0386,735$ & 0,000 & ditolak \\
\hline
\end{tabular}

Keterangan: $\mathrm{H}_{\mathrm{o}}$ : Tidak ada perbedaan peningkatan soft skills antara kedua kelompok pembelajaran

Tabel 5. Hasil Uji ANOVA Dua Jalur Data Peningkatan Soft Skills Siswa Berdasarkan Kelompok Pembelajaran dan Level Sekolah

\begin{tabular}{lccccc}
\hline Sumber & Jumlah Kuadrat & df & Rata-rata Kuadrat & F & Sig. \\
\hline Intercept & 2,506 & 1 & 2,506 & 106,607 & 0,000 \\
Pembelajaran & 1,103 & 1 & 1,103 & 46,933 & 0,000 \\
Level Sekolah & 0,188 & 2 & 0,094 & 3,993 & 0,020 \\
Pembelajaran* & 0,113 & 2 & 0,057 & 2,410 & 0,093 \\
level Sekolah & & & & & \\
Kesalahan & 4,349 & 185 & 0,024 & & \\
Total & 8,242 & 191 & & & \\
\hline
\end{tabular}

Interaksi antara pembelajaran dan level sekolah terhadap peningkatan soft skills siswa interaksi antara pembelajaran MPG dan MPK dengan level sekolah (tinggi, sedang, dan rendah) terhadap peningkatan soft skills siswa diperoleh dari perhitungan menggunakan uji Anova dua jalur melalui GLM. Hasil perhitungan disajikan pada Tabel 5 .

Terlihat bahwa perbedaan penggunaan kelompok pembelajaran berpengaruh secara signifikan terhadap peningkatan softskills siswa. Ada perbedaan level sekolah (tinggi, sedang, dan rendah) berpengaruh terhadap peningkatan soft skills siswa. Model pembelajaran (MPG dan MPK) dengan level sekolah (tinggi, sedang, dan rendah) tidak berinteraksi secara signifikan dalam peningkatan soft skills siswa. Secara grafis terlihat pada Gambar 1.

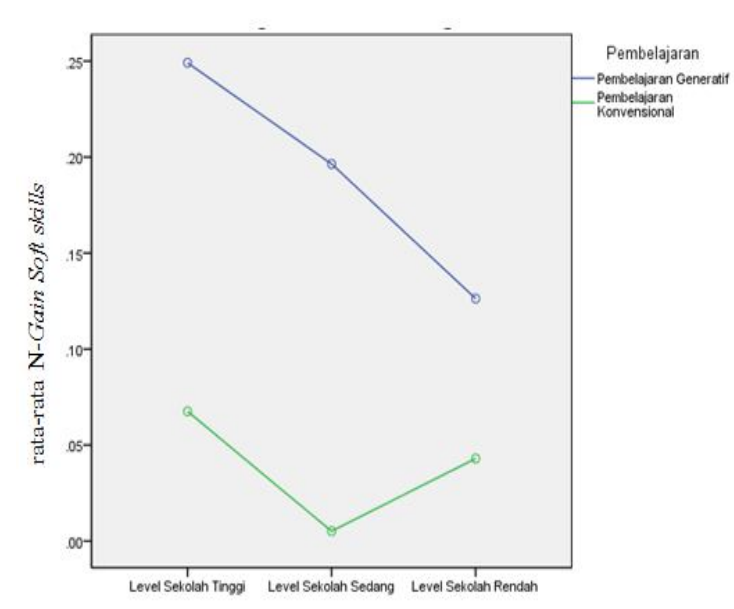

Gambar 1. Interaksi antara Pembelajaran dan Level Sekolah terhadap Peningkatan Soft Skills

Berkaitan dengan Gambar 1, tampak bahwa peningkatan rata-rata soft skills siswa dengan menggunakan MPG sesuai untuk semua siswa baik level sekolah tinggi, level sekolah 
sedang, dan level sekolah rendah. Tampak bahwa skor rata-rata N-Gain siswa pada level sekolah tinggi dalam pembelajaran generatif memberikan manfaat yang sangat besar dan diikuti oleh siswa pada level sekolah sedang dalam penggunaan pembelajaran generatif bila dibandingkan dengan siswa yang berada level sekolah rendah. Selain itu, terlihat bahwa tidak terjadi interaksi antara faktor pembelajaran dan level sekolah dalam peningkatan soft skills siswa.

\section{Pembahasan}

\section{Pencapaian Soft Skills Siswa}

Hasil penelitian menunjukkan bahwa terdapat perbedaan yang signifikan pencapaian soft skills siswa antara yang memperoleh pembelajaran generatif dan siswa yang memperoleh pembelajaran konvensional. Hal ini didasarkan dengan peroleh skor rata-rata postes soft skills siswa antara kelas eksperimen dan kelas kontrol yang menunjukkan perbedaan yang signifikan sehingga memberikan dampak positif bagi siswa untuk mengembangkan pencapaian soft skills siswa dalam pembelajaran matematika.

Ada perbedaan skor rata-rata pencapaian soft skills siswa untuk kelas eksperimen atau kelas yang memperoleh pembelajaran generatif lebih besar daripada kelas kontrol. Perbedaan kedua skor rata-rata tersebut dilakukan uji statistik diperoleh bahwa terdapat perbedaan pencapaian soft skills siswa yang memproleh pembelajaran generatif lebih baik daripada siswa yang memperoleh pembelajaran konvensional. Hasil pengujian ini mengindikasikan bahwa faktor pembelajaran MPG berpengaruh secara signifikan dalam pencapaian soft skills siswa. Ini berarti bahwa penerapan pembelajaran generatif memberikan kontribusi terhadap pencapaian soft skills siswa, serta dipicu oleh bahan ajar matematika yang digunakan. Pembelajaran matematika yang dilakukan di kelas dengan mengacu pada karakteristik pembelajaran generatif akan memungkinkan tumbuhnya soft skills siswa, dan rasa ingin tahu siswa, dan kerja keras dalam belajar matematika.

Hasil penelitian ini memperkuat pendapat Goleman (1999:38) bahwa keberhasilan kita dalam kehidupan ditentukan oleh keduanya, tidak hanya oleh IQ, tetapi kecerdasan emosional yang memegang peranan. Selanjutnya, Patton (Uno, 2008:70) mengatakan bahwa hubungan IQ dan EI sebagai berikut. IQ adalah faktor genetik yang tidak dapat berubah yang di bawah sejak lahir, sedangkan EI tidak demikian, karena dapat disempurnakan dengan kesungguhan, pelatihan, pengetahuan, dan kemauan. Dasar untuk memperkuat EI seseorang adalah dengan memahami diri sendiri, giat dan bekerja keras. Selain itu, Kaipa, dkk. (2005:19) mengemukakan bahwa soft skills saja tidak membuat seseorang sukses, namun perlu ada keseimbangan dengan memiliki managemen tim hard skills/ keterampilan profesional yang tepat, menciptakan sistem managemen sumber daya manusia yang mendukung tim dapat melipatgandakan peluang kesuksesan seseorang.

Penjelasan tersebut menunjukkan bahwa kesuseksan seseorang harus ada keseimbangan dari ranah hard skills dan soft skills. Demikian halnya hasil temuan AGR (Schulz, 2008:146), bahwa banyak lulusan PT kurang soft skills seperti tim kerja, dan juga mereka juga mengatakan bahwa lulusan PT mahir akademik tetapi kurang dalam keterampilan soft skills seperti komunikasi, serta penalaran verbal, dan numerik.

Uraian di atas dapat mendukung hasil temuan penelitian ini bahwa pencapaian soft skills siswa antara yang memperoleh pembelajaran generatif lebih baik daripada siswa yang memperoleh pembelajaran konvensional.

\section{Peningkatan Soft Skills Siswa}

Hasil penelitian menunjukkan bahwa terdapat perbedaan yang signifikan peningkatan soft skills antara siswa yang memperoleh pembelajaran generatif dan siswa yang memperoleh pembelajaran konvensional. Hasil temuan penelitian ini sejalan dengan hasil penelitian tentang relasi manusia menunjukkan bahwa salah satu cara untuk menjalin relasi yang sehat dan mendapatkan kepuasan sejati adalah dengan membina hubungan yang baik dengan sesama manusia tetap menjaga keutuhan ego kita dan sesama (Chen, 2012: xv). 
Dalam proses pembelajaran generatif, yaitu pada saat siswa berdiskusi dalam kelompok yang beranggotakan 3-4 orang siswa, di sini siswa kategori pandai tidak mendominasi segala aktivitas dalam kelompok, tetapi dia bisa membantu teman-teman yang lain dalam satu kelompok yang mengalami kesulitan memahami konsep sehingga siswa tersebut dengan mudah mencerna materi pelajaran yang diberikan oleh guru.

Pembelajaran generatif pada langkah ke2 dan ke-3 siswa dituntut untuk menumbuhkan kepercayaan diri siswa untuk menyelesaikan setiap masalah yang dihadapinya dalam pembelajaran matematika. Selain itu, siswa dituntut mampu berkomunikasi secara efektif, bekerja sama dengan orang lain (dalam tim), tumbuh motivasi diri, kerja keras. Hal seperti ini telah dilakukan dalam pembelajaran generatif.

Uraian di atas menguatkan temuan hasil penelitian bahwa pembelajaran generatif dapat memberikan perbedaan peningkatan soft skills siswasecara signifikan.

Interaksi antara Pembelajaran dan Level Sekolah terhadap Peningkatan Soft Skills Siswa

Hasil temuan dalam penelitian ini menunjukkan bahwa tidak terdapat interaksi antara pembelajaran dan level sekolah secara signifikan dalam peningkatan soft skills siswa. Temuan lain dari penelitian ini adalah bahwa terdapat perbedaan rata-rata peningatan soft skills siswa antara level sekolah tinggi dan level sekolah rendah. Hal ini dapat dilihat pada Tabel 5, sedangkan antara siswa pada level sekolah sedang dan rendah tidak terdapat perbedaan yang signifikan, dan tidak terdapat perbedaan rata-rata peningkatan soft skills siswa pada level sekolah tinggi dan level sekolah sedang.

Hasil penelitian ini relevan dengan pendapat Widhiarso (2009:1) bahwa soft skills adalah seperangkat kemampuan yang memengaruhi bagaiman kita berinteraksi dengan lain. Soft skills memuat komunikasi efektif, berpikir kreatif, dan kritis, membangun kerjasama tim, serta kemampuan lainnya yang terkait dengan kapasitas kepribadian individu.

\section{PENUTUP}

Berdasarkan hasil penelitian dapat dibuat kesimpulan sebagai berikut.

Pertama, pencapaian soft skills siswa yag memperoleh pembelajaran generatif lebih baik daripada siswa yang memperoleh pembelajaran konvensional. Secara keseluruhan pencapaian soft skills siswa yang menggunakan pembelajaran generatif termasuk kategori level sedang.

Kedua, peningkatan soft skills siswa yang memeroleh pembelajaran generatif lebih baik daripada siswa yang memperoleh pembelajaran konvensional. Secara keseluruhan peningkatan soft skills siswa yang memeroleh pembelajaran generatif termasuk kategori level rendah.

Ketiga, tidak terdapat interaksi antara pembelajaran dan level sekolah (tinggi, sedang, rendah) terhadap peningkatan soft skills siswa SMP.

\section{UCAPAN TERIMA KASIH}

Ucapan terima kasih diucapkan kepada semua pihak yang telah membantu pelaksanaan penelitian ini, terutama kepada para guru di SMPN Yogyakarta yang sebagai sampel penelitian telah melayani dalam berbagai kebutuhan.

\section{DAFTAR PUSTAKA}

Abdullah, I. 2012. "Peningkatan Kemampuan Pemahaman Matematis dan Representasi Matematis Siswa SMP melalui Pembelajaran Kontekstual Berbasis Soft Skills". Ringkasan Disertasi. Tidak Dipublikasikan. SPS UPI.

Chen, F. V. 2012. Soft Skills for Success, Series. Pendai Membawa Diri di Dunia Kerja. Jakarta: Bhuana Ilmu Populer.

Elfindri, Elmiyasna, Mitayani, Biomed, Hasnita, E, Abidin, Z. 2009. Soft Skills untuk Panduan bagi Bidang dan Perawat. (Tanpa Kota): Baduose Media.

Elfindri, Rumengan, J, Wello, M. B, Tobing, P, Yanti,F, Eriyani, Z.E, Indra, R. 2010. 
Soft Skills untuk Pendidik. (Tanpa Kota): Baduose Media.

Fahinu. 2007. "Meningkatkan Kemampuan Berpikir Kritis dan Kemandirian Belajar Matematika pada Mahasiswa melalui Pembelajaran Generatif". Disertasi. Tidak Diterbitkan.UPI.

Gardner, H. 1993. Multiple Inteligences. The Theory in Practice. New York: Basic Books.

Goleman, D. 1999. Emotional Intelligence. Kecerdasan Emosional. Alihbahasa: Hermaya, T. Jakarta: Gramedia Pustaka Pertama.

Haji, S. 2011. "Mengembangkan Kemampuan Kemampuan Berpikir Asli melalui Pembelajaran Generatif dengan Pendekatan Open-ended'. Journal Pasundan. Journal of Mathematics Education. Tahun I No.1. ISSN 2089-2055.

Kaipa, P., \& Milus.T. 2005. Soft skills are Smart Skills. [online]. Tersedia: kaipagroup.com/articles/softskills.pdf. Diundu 23 April 2013.

Nyoman, I. S. 2009. Holistik Soft Skills. Bali: Udayana University Press.

Osborne, R. J., \& Wittrock, M. C. 1985. "The Generative Learning Model and its Implication for Science Education". Studies in Science Education, 12, 59-87.
Ruseffendi, H. E.T. 2005. Dasar-dasar Penelitian Pendidikan \& Bidang Non-Eksakta Lainnya. Bagi: Para Peneliti, Penulis Skripsi, Penulis Tesis, Penulis Disertasi, Dosen Metode Penelitian dan Mahasiswa. Bandung: Tarsito.

Schulz, B. 2008. "The Importance of Soft Skills: Education Beyond Academic Knowledge". NAWA. Journal of Language and Communication. [Online]: Tersedia http://www.google.com./search?hl=en\&source $=\mathrm{hp} \& \mathrm{q}=$ schulz.B. +2008 +NAWA,+journal+of+language+and+co mmunication.Soft+skills+\&. Diundu 20 April 2013.

Shapiro, E. L. 1997. Mengajarkan Emotional Intelligence pada Anak. Jakarta: Gramedia Pustaka Utama.

Uno, B. H., \& Kuadrat, M. 2009. Mengelola Kecerdasan dalam Pembelajaran sebuah Konsep Pembelajaran Berbasis Kecerdasan. Jakarta: Bumi Aksara.

Widhiarso, W. 2009. "Evaluasi Soft Skills dalam Pembelajaran. Makalah. Disampaikan pada Kegiatan Seminar dan Sarasehan "Evaluasi Pembelajaran Mata Kuliah Umum kependidikan". Yogyakarta. FIP UNY. 